\title{
Bioactivity of Locally Available Plants on Cotton Whitefly, Bemisia tabaci and the fungus isolated from cotton
}

\author{
Dhananjay B. Alagundagi, Samrin H. Nadaf, Aarti H. Ghodke, Chandrakala C. Swami, \\ Gopika Manjunath*
}

Assistant Professor, Department of Biotechnology, V.G.Shivdare College of Arts, Commerce and Science, Jule -Solapur, Solapur, (Affiliated to Solapur University Solapur), Maharashtra, India

\begin{abstract}
Aqueous, diethyl ether, chloroform, petroleum ether, $N$-hexane and benzene extracts of locally available plant species were tested for phytochemical and insecticidal bioactivity against cotton whitefly, Bemisia tabaci, under controlled conditions. This study is within bioprospection context, for utilizing local plant species as alternative in sustainable agriculture development. The leaf and stem extract was used. The whole plant extract of T.procumbens followed by N.oleander and V.rosea showed repellent and toxic effect against adult and second nymphal instars. Leaf extract of all three plants showed high inhibition activity against nymphal instars. In case of flower extract less inhibition activity was shown respectively. Fungi which grow on the cotton plant was screened, characterized and checked for antifungal activity against the extracts of the plant material. Phytochemical analysis was also carried out by standard protocols.
\end{abstract}

Keywords- biological control, cotton, fungus, insecticides, phytochemicals, whitefly.

\section{INTRODUCTION}

Cotton being a natural fiber is one of the economically and socially important crop. It is a shrub, native to tropical and subtropical regions of the world. India is the second largest cotton producing country all over the world. But as per the recent studies, the crop yield of cotton is reducing year by year. Two years ago, the reduction in the crop yield was up to $5 \%$. But now, it is increased up to $35 \%$ (K.R. Kranthi 2015). This is a threatening fact to the farmers. The main reason behind the reduction in crop yield is a disease called as 'whitefly disease'. It is caused by whitefly, Bemisia tabaci, a small sap sucking insect. Its body is white or pale yellow in colour. The eggs are very small, having size up to $0.1 \mathrm{~mm}$ while the nymph and pupae grow up to $1 \mathrm{~mm}$ (Scott D. Stewart 1914.). The infection carried out by direct and indirect feeding. Direct feeding is by sucking sap and release of honeydew. Indirect feeding is by honeydew. Honeydew, being a sugary substance attracts the ants which interfere with the natural enemies of whitefly. Honeydew is also responsible for the growth of black sooty mold below the leaves. (K.R. Kranthi, 2015).

T. procumbens is a weed well known for its medicinal properties. (Suseel et al. 2002). It is having antimicrobial activity, antibiotic, antispasmodics and anti-cancer properties. $N$. oleander is used in the treatment of cancer, leprosy and skin diseases. It is an evergreen shrub and have fragrant flowers. $V$. rosea is an important medicinal plant. It is an evergreen and perennial shrub. It is useful against a great variety of diseases such as diabetes, mouth ulcers, leukemia etc. It also shows anti microbial activity, anti mutagenic effect and anti oxidant activity. (Punia Sandeep, 2014).

The cotton growing farmers use much of the pesticide against the cotton whitefly. These chemicals are believed to affect the soil and groundwater.

Synergized pyrethroid cannot be used for more than two treatments, as the treatments show decreased efficiency in cotton while buprofezin is highly efficient to field but can be used once per season. The pyriproxyfen show great resistance. Previously imidacloprid was mostly used for cotton crop; but now-a-days it is used only for foliar treatment. Whiteflies from different host differ in susceptibility when exposed to imidacloprid. (UAC 2006)

The aim of the study is to extract the metabolites from different plants, their screening for phytochemical properties of extracts and bioinsecticide activity on infected cotton.

\section{MATERIALS AND METHODS}

2.1 Plant collection and processing 
The plant samples (V. rosea, $T$. procumbens and $N$. oleander) were collected from the campus area of V.G.Shivdare College, Solapur and Arjnal, Karnataka in August, 2016.

The plant materials (leaves and stems) were sterilized by treating with tap water and $70 \%$ alcohol. Then the plant materials were dried in hot air oven at $130^{\circ} \mathrm{C}$ for $15 \mathrm{~min}$. The dried samples were powdered in mixture grinder.

\subsection{Preparation of plant extracts}

$5 \mathrm{gm}$ powder of each plant material was dissolved in $50 \mathrm{ml}$ of different solvents. The solvents used were water, chloroform, diethyl ether, benzene, n-hexane and petroleum ether. Then the suspensions were incubated for $4 \mathrm{hrs}$ at room temperature on orbital shaker. Then the suspensions were filtered and dried at $110^{\circ} \mathrm{C}$ in hot air oven. Finally the extracts were dissolved in $0.25 \%$ DMSO and used as a stock solution.

\subsection{Phytochemical analysis}

Phytochemical properties analyses were performed according to (Oloyed 2005).

\subsection{Collection of Infected leaves}

The cotton leaves infected by the whitefly were collected from a village Arjnal, Karnataka in the month of August 2016. The plant was 2 months old and was in blossom stage.

\subsection{Study for bioactive activity}

The aqueous, diethyl ether, chloroform, benzene, N-hexane and petroleum ether extracts of the plant material were sprayed on the infected cotton leaves. Then these leaves were stored in air free plastic bottles to check the bioactivity.

\subsection{TLC and Paper Chromatography}

Silica gel slurry is prepared by dissolving $36.6 \mathrm{gm}$ of silica gel in $100 \mathrm{ml} \mathrm{D} / \mathrm{W}$. Then it is poured on TLC plates. Then the plates were incubated in the oven at $60^{\circ} \mathrm{C}$ for 30 minutes. After incubation, $10 \mu \mathrm{l}$ of each sample was loaded on the TLC plates and allowed to dry in hot air oven. Further the TLC plates were run in different solvent system (mobile phase) up to $3 / 4^{\text {th }}$ of the plate. Then the plates were removed and allowed to dry. Then drying reagents were spread. The different solvent system and their spraying reagents are listed below. After spraying the reagent, the spots were detected and RF value is calculated. The solvent systems used are as follows:
Alkaloids: Methanol: Ammonium hydroxide [17:3]

Saponins: Chloroform: Glacial acetic acid: Methanol: Water [6:2:1:1]

Terpenoids: Benzene: Ethyl acetate [95:5]

Flavanoids: N-butanol: Glacial acetic acid: Water [4:1:5]

Chloroform: Acetone [2:1]

Chloroform: Methanol [2:2]

\subsection{Cultivation of fungal culture}

The fungal culture was isolated from infected cotton leaves and then inoculated on the solidified Potato Dextrose Agar media and incubated at $25^{\circ} \mathrm{C}$ for $3-5$ days. Then the colony morphology was determined by microscopic analysis and is represented in the result.

\subsection{Antifungal activity by well diffusion method}

The SDA media containing $0.1 \%$ of starch is used to check antifungal activity. The media and petriplates were sterilized at $121^{\circ} \mathrm{C}$ at $15 \mathrm{lbs}$ pressure for 20 minute. After sterilization, media is poured onto the plates at warm temperature $42^{\circ} \mathrm{C}-45^{\circ} \mathrm{C}$, and then the plates were kept for solidification. The different colonies of culture were spreaded using the sterile cotton swab. After spreading, the wells were punched by using well puncher. The plant extract with the concentration of $1 \mathrm{mg} / \mathrm{ml}$ were prepared of $T$. procumbens, $N$. oleander and $V$. rosea of stem and leaves. Each 20 microlitre of plant extract is loaded onto the wells and incubated at $28^{\circ} \mathrm{C}$ for 3-5 days. The zone of inhibition is determined and shown in Table no.7.

\subsection{Lab trial of Plants}

The seeds of cotton, $V$. radiate and $V$. aconitifolia were sown in the soil in the tray with distance of $2 \mathrm{~cm}-5 \mathrm{~cm}$. Then the tray is kept in light and the growth of plant is checked.

The plants were infected with the fungal culture isolated from cotton plants and rate of fungal infection was checked. The infected leaves were treated with plant extract of $T$. procumbens, $N$. oleander and $V$. rosea dissolved in DMSO with concentration of $1 \mathrm{mg} / \mathrm{ml}$. A control was kept without addition of any solution. After the treatment the trays were incubated in light and result are shown in Table no 8.

\subsection{Phytochemical Analysis}

\section{RESULT}

\subsubsection{Tridax. procumbens}

In the present study, the alkaloids show negative results in the aqueous, diethyl ether and chloroform extract of the leaf of $T$. procumbens. The aqueous leaf extracts shows presence of flavonoids. The diethyl ether and chloroform 
extract of leaf shows presence of saponin, tannins and amino acid. Petroleum ether extracts shows presence of tannin, alkaloids, saponin and amino acid. In Benzene extracts tannin, alkaloids, amino acid were present while in n-hexane only amino acid were present.

The chloroform extract of the stem shows the presence of flavonoids while the aqueous extract shows presence of saponin. Diethyl ether extract shows presence of flavonoids and tannin. Petroleum ether stem extracts shows presence of saponin and tannin while aqueous and benzene shows presence of Saponin and tannin respectively. Amino acid and alkaloids are absent in stem extracts. (Table no.1 and 2)

\subsubsection{Nerium oleander}

In $N$. oleander, n-hexane, aqueous, diethyl ether and chloroform leaf extract shows negative results for alkaloids but only petroleum ether and benzene shows positive results for alkaloids. The aqueous, petroleum ether, n-hexane and benzene extract of leaf shows positive results for flavonoids, saponin and tannins. The diethyl ether extracts shows presence of amino acid and tannins while chloroform extracts shows presence of amino acid, tannins.

All extract of stem shows absence of alkaloids and amino acid while the aqueous extract shows presence of flavonoid and saponin. Diethyl ether shows presence of saponin and tannin while petroleum ether, n-hexane and benzene extract shows presence of tannin. (Table no.1 and 2)

\subsubsection{Vinca rosea}

The aqueous, diethyl ether, petroleum ether, benzene, nhexane and chloroform extract of the leaves of $V$. rosea shows presence of alkaloids and flavonoids. The aqueous leaf extract shows presence saponins and tannins. The diethyl ether, n-hexane, benzene and chloroform extract of leaf contains tannins and amino acid. In diethyl ether, benzene, petroleum ether, n-hexane shows amino acid presence.

All the extracts of stem show absence of alkaloid and amino acid. The chloroform extract shows presence of tannin, flavonoid. Petroleum ether and n-hexane shows presence of tannin and saponin. Diethyl ether and benzene shows presence of flavonoid and Saponin respectively. (Table no. 1 and 2)

\subsection{TLC}

Diethyl ether, aqueous, chloroform extract of $T$. procumbens leaves showed positive results in flavonoid as well as in saponin. Diethyl ether extract of $N$. oleander leaves showed positive results in both flavonoid and terpenoids. Chloroform extract showed positive result in terpenoid. $V$. rosea leaves showed positive results of diethyl ether, aqueous and chloroform extract only in flavonoid.

N-hexane extract of $T$. procumbens stem showed positive results in saponin, chloroform: methanol and chloroform: acetone. Benzene extract showed positive result in saponin and chloroform: acetone. N-hexane, benzene, petroleum ether extract of $N$. oleander and $V$. rosea stem showed positive results in saponin and petroleum ether extract of $N$ .oleander showed positive result in chloroform: methanol. $\mathrm{RF}$ values of this result were calculated and tabulated in table no. 3 and 4 (figure no.4)

\subsection{Study of infection rate}

Study of infection rate is been discussed in table no. 5. Field study was done at Arjanal from month of June-September. The infection was observed in the month of August 2016. The plant was in the blossom stage. The infected cotton leaves were collected and the number of mobile crawlers, nymphs and the adults were counted under inverted microscope. We found 60-70 crawlers on each leaf. The number of adult and nymphal was comparatively less. (Table no.5)

\subsection{Study for the bioactivity}

The aqueous, diethyl ether, chloroform, petroleum ether, $\mathrm{N}$ hexane and benzene extract were sprayed on the infected leaves. Then the leaves were kept in air free plastic bottles. We observed that the whole plant extract of the plant material (leaves, stem) showed repellent and toxic activity. Stem and leaf extract of $T$. procumbens showed same rate of $\%$ mortality. N. oleander leaf extract showed more $\%$ mortality than stem. V. rosea leaf extract showed more $\%$ mortality than stem. (Table no.6)

\subsection{Cultivation of fungal culture.}

The fungal growth observed on PDA plate which was obtained from cotton leaves infected by fungus. Black, white, green, orange and yellow colour colonies were observed on PDA plate. All these colonies were round in shape and had dry consistency. (Figure 5)

\subsection{Microscopic identification of fungal culture}

Identification of fungal culture is done by Lactophenol cotton blue staining. It showed rod shape, light pink and violet in colour with filamentous structure as shown in figure 6 .

\subsection{Antifungal activity}


In the present study the antifungal activity of plant extract of T.procumbens, N.oleander and v.rosea of concentration $1 \mathrm{mg} / \mathrm{ml}$ showed zone of inhibition activity with diameter of $1.3 \mathrm{~cm}, 1.2 \mathrm{~cm}, 1.2 \mathrm{~cm}$ respectively and the zone of inhibition for standard antibiotic disc used i.e. Gentamycin of $30 \mathrm{mg} / \mathrm{ml}$ concentration has shown $0.5 \mathrm{~mm}$ size of zone inhibition respectively as shown in figure 7 and 8 . The results are tabulated in table no.7.

\subsection{Infection treatment for different plant varieties}

In the present study, cotton, V.radiate and V.aconitifolia were cultivated. The height of cotton seedling was in range between $2.5 \mathrm{~cm}$ to $5.5 \mathrm{~cm}$ with leaves of length ranging between $2.7 \mathrm{~cm}$ to $3.1 \mathrm{~cm}$, height of green peas seedling ranges between $5.5 \mathrm{~cm}$ to $9 \mathrm{~cm}$ with leaves of length $1 \mathrm{~cm}$ to $1.5 \mathrm{~cm}$ and the height of V.aconitifolia seedling ranges between $6.9 \mathrm{~cm}$ to $10 \mathrm{~cm}$ with leaves of length $1.8 \mathrm{~cm}$ to $2.5 \mathrm{~cm}$ as shown in figure. The control were infected by fungal culture for V.radiate, V.aconitifolia and these were shown the morphological changes in their height and leaves with characteristic of shrinking of leaves, blunting of stem as shown in figure 93.9 Comparative study of plant extract against fungal infection and whitefly infection.

Total of 100 plants cultivated, some were kept uninfected as control and some were infected with $18 \mathrm{hrs}$ culture. The plants infected by fungal culture for V.radiate and V.aconitifolia showed morphological changes in their height and leaves with characteristic shrinkage of leaves and blunting of stem. Comparative study of plant extract against fungal infection and the cotton plant infected by whitefly was carried out. The control show no morphological changes and black spots were observed which later dried up.(figure no10)

\section{DISCUSSION}

Previous studies have reported that a number of medicinal plant species tested in this study showed certain effect on insects (Abou-Fakhr Hammad et al. 2005; Mahdavi-Arab et al. 2008; Jafarbeigi, et al 2012). In the present study the potential effects on survival of insects for the locally available plant species such as $T$. procumbens, N.oleander and $V$. rosea observed.

In this study an aqueous, diethyl ether and chloroform extract of T.procumbens, N.oleander and V.rosea were applied to whitefly infected cotton leaves to check the insecticidal activity. The whole plant extract of T.procumbens followed by N.oleander and V.rosea shows repellent and toxic effect against the adult and second nymphal instars. Leaf extracts of three plants showed high inhibition activity against nymphal instars. In case of flower extract less inhibition activity was shown respectively.

The phytochemical analysis is done to evaluate active biological components in the plants. For this purpose aqueous, diethyl ether and chloroform extraction was used. The aqueous extract of N.oleander found to contain carbohydrates, proteins, amino acids, alkaloids and cardiac glycosides. Tannins and saponins are present in N.oleander. The diethyl ether extract shows the presence of carbohydrate, protein, amino acids, sterols and alkaloids. Flavonoids and alkaloids were absent. Carbohydrate, proteins, amino acids and glycosides were present in chloroform extract. Alkaloids, flavonoids and saponins were absent. (Santhi $\mathrm{R}$ et al , 2011).In our recent study the aqueous, diethyl ether and chloroform extract of the N.oleander showed presence of flavonoids, tannin and saponnins.

T.procumbens is a widely spread weed. It's each and every part is useful having pharmacological activity. It showed presence of flavonoids, saponins, and tannins. Leaves have various activities such as wound healing, antidiabetic activity, against conjuctivities, insect repellent activity etc. Flowers and leaves have insecticidal activity. (Jain Ankita and Amita Jain 2012). During our study we found the flavonoids, saponins, and tannins.

$V$. rosea is an evergreen sub shrub. The leaf extract shows antibacterial activity. While studying on V.rosea we found alkaloids, flavonoids, saponins and tannin were present in aqueous extract of leaves, flowers and stem while glycosides were absent in aqueous leaf and flower extract. The diethyl ether extract showed presence of glycosides, alkaloids, flavonoids and tannin while the saponins were absent.

In the study Abou et al 2014, the cucumber plants with methanol extract of several medicinal plants showed toxic effect against B.tabaci, depending upon specific extracted plant part. Among four extracted plant parts flower, leaf, stem extracts are significantly as showed inhibition activity. Similarly in our study the flower extract of V.rosea, T.procumbens and N.oleander has shown high mortality rate against infected leaves. Whereas stem and leaves of three different plants extracts has shown less inhibition activity respectively as shown in Table no 6 .

\section{CONCLUSION}

Previous studies had reported the different medicinal plant species, which showed effect on certain insects. In this present study the potential effect of locally available plant 
species such as T.procumbens N.oleander and V.rosea is used and its bioactivity on white fly is been studied

Phytochemicals are compounds which have no basic fundamental role in maintaining life process. But play an important role for adaption and defense of plants against different conditions.

T.procumbens, N.oleander and V.rosea show positive result for presence of the flavonoids, alkaloids saponin, amino acids, glycosides etc. which we can conclude that these phytochemical have the antibacterial, antifungal and enhance the tolerance in plants.

The evaluation of the phytochemical in the plants was confirmed by TLC and all plant extracts confirmed the presence of phytochemicals in varying ratios.

The overall results revealed that plant extracts are more efficient as compared to the synthetic insecticides used. Use of pesticides for the control of whitefly creates many adverse effects including pesticide resistance and it also reduces the fertility of the soil. The farmers can easily use the plant materials. These are not expensive, grow everywhere and are having more bioactivity. The plant material, the life cycle or the growth stages of insects, the plant species and the location of collection plays important role in the study of bioactivity of plant extracts against whitefly.

This study is within bioprospection context, for utilizing local plant species as alternative in sustainable agriculture development. The leaf, flower and stem extract was used. The whole plant extract of T.procumbens followed by N.oleander and V.rosea showed repellent and toxic effect against adult and second nymphal instars. Leaf extract of all three plants showed high inhibition activity against nymphal instars.

\subsection{Result for Phytochemical Analysis:}

\section{TABLES}

\begin{tabular}{|c|c|c|c|c|c|c|c|c|c|}
\hline $\begin{array}{l}\text { SR } \\
\mathrm{N} \\
\mathrm{O}\end{array}$ & $\begin{array}{c}\text { PLANT } \\
\text { MATER } \\
\text { IAL }\end{array}$ & PLANT & $\begin{array}{c}\text { PHYTOCHEM } \\
\text { ICALS }\end{array}$ & $\begin{array}{c}\text { AQUAE } \\
\text { OUS }\end{array}$ & $\begin{array}{c}\text { DIET } \\
\text { HYL } \\
\text { ETHE } \\
\text { R }\end{array}$ & $\begin{array}{c}\text { CHLO } \\
\text { ROFO } \\
\text { RM }\end{array}$ & $\begin{array}{c}\mathrm{N}- \\
\text { HEXAN } \\
\text { E }\end{array}$ & $\begin{array}{l}\text { BENZ } \\
\text { ENE }\end{array}$ & $\begin{array}{c}\text { PETROL } \\
\text { EUM } \\
\text { ETHER }\end{array}$ \\
\hline \multirow[t]{15}{*}{1} & LEAF & $\begin{array}{c}\text { TRIDAX } \\
\text { PROCUMB } \\
\text { ENS }\end{array}$ & ALKALOIDS & - & - & - & - & + & + \\
\hline & & & FLAVONOID & + & - & - & - & - & - \\
\hline & & & SAPONIN & - & + & + & - & - & + \\
\hline & & & TANNIN & + & + & + & - & + & + \\
\hline & & & $\begin{array}{l}\text { AMINO } \\
\text { ACIDS }\end{array}$ & - & + & + & + & + & + \\
\hline & & $\begin{array}{c}\text { NERIOUM } \\
\text { OLEANDER }\end{array}$ & ALKALOIDS & - & - & - & - & + & + \\
\hline & & & FLAVONOID & + & - & - & + & + & + \\
\hline & & & SAPONIN & + & - & - & + & + & + \\
\hline & & & TANNIN & + & + & + & + & + & + \\
\hline & & & $\begin{array}{l}\text { AMINO } \\
\text { ACIDS }\end{array}$ & - & + & + & + & + & + \\
\hline & & $\begin{array}{l}\text { VINCA } \\
\text { ROSEA }\end{array}$ & ALKALOIDS & + & + & + & + & + & + \\
\hline & & & FLAVONOID & + & + & + & + & + & + \\
\hline & & & SAPONIN & + & - & - & - & - & - \\
\hline & & & TANNIN & + & + & + & + & + & - \\
\hline & & & $\begin{array}{l}\text { AMINO } \\
\text { ACIDS }\end{array}$ & - & + & + & + & + & + \\
\hline
\end{tabular}




\begin{tabular}{|c|c|c|c|c|c|c|c|c|c|}
\hline \multicolumn{10}{|c|}{ Table.2: Phytochemical analysis } \\
\hline $\begin{array}{l}\text { SR } \\
\text { N } \\
\text { O. }\end{array}$ & $\begin{array}{c}\text { PLANT } \\
\text { MATERI } \\
\text { AL }\end{array}$ & PLANT & $\begin{array}{c}\text { PHYTOCHEMI } \\
\text { CALS }\end{array}$ & $\begin{array}{c}\text { AQUAEO } \\
\text { US }\end{array}$ & $\begin{array}{l}\text { DIETH } \\
\text { YL } \\
\text { ETHER }\end{array}$ & $\begin{array}{c}\text { CHLOROFO } \\
\text { RM }\end{array}$ & $\begin{array}{c}\mathrm{N}- \\
\text { HEXA } \\
\mathrm{NE}\end{array}$ & $\begin{array}{c}\text { BENZE } \\
\text { NE }\end{array}$ & $\begin{array}{c}\text { PETROLE } \\
\text { UM } \\
\text { ETHER }\end{array}$ \\
\hline 2 & STEAM & $\begin{array}{c}\text { TRIDAX } \\
\text { PROCUMB } \\
\text { ENS }\end{array}$ & ALKALOIDS & - & - & - & - & - & - \\
\hline & & & FLAVONOID & - & + & + & - & - & - \\
\hline & & & SAPONIN & + & - & - & - & - & + \\
\hline & & & TANNIN & - & + & - & - & + & + \\
\hline & & & AMINO ACIDS & - & - & - & - & - & - \\
\hline & & $\begin{array}{c}\text { NERIOUM } \\
\text { OLEANDE } \\
\mathrm{R}\end{array}$ & ALKALOIDS & - & - & - & - & - & - \\
\hline & & & FLAVONOID & + & - & - & - & - & - \\
\hline & & & SAPONIN & + & + & - & - & - & - \\
\hline & & & TANNIN & - & + & - & + & + & + \\
\hline & & & AMINO ACIDS & - & - & - & - & - & - \\
\hline & & $\begin{array}{l}\text { VINCA } \\
\text { ROSEA }\end{array}$ & ALKALOIDS & - & - & - & - & - & - \\
\hline & & & FLAVONOID & - & + & + & - & - & - \\
\hline & & & SAPONIN & - & - & - & + & + & + \\
\hline & & & TANNIN & - & - & + & + & - & + \\
\hline & & & AMINO ACIDS & - & - & - & - & - & - \\
\hline
\end{tabular}

6.2 Result for TLC

Table.3: Thin Layer Chromatography

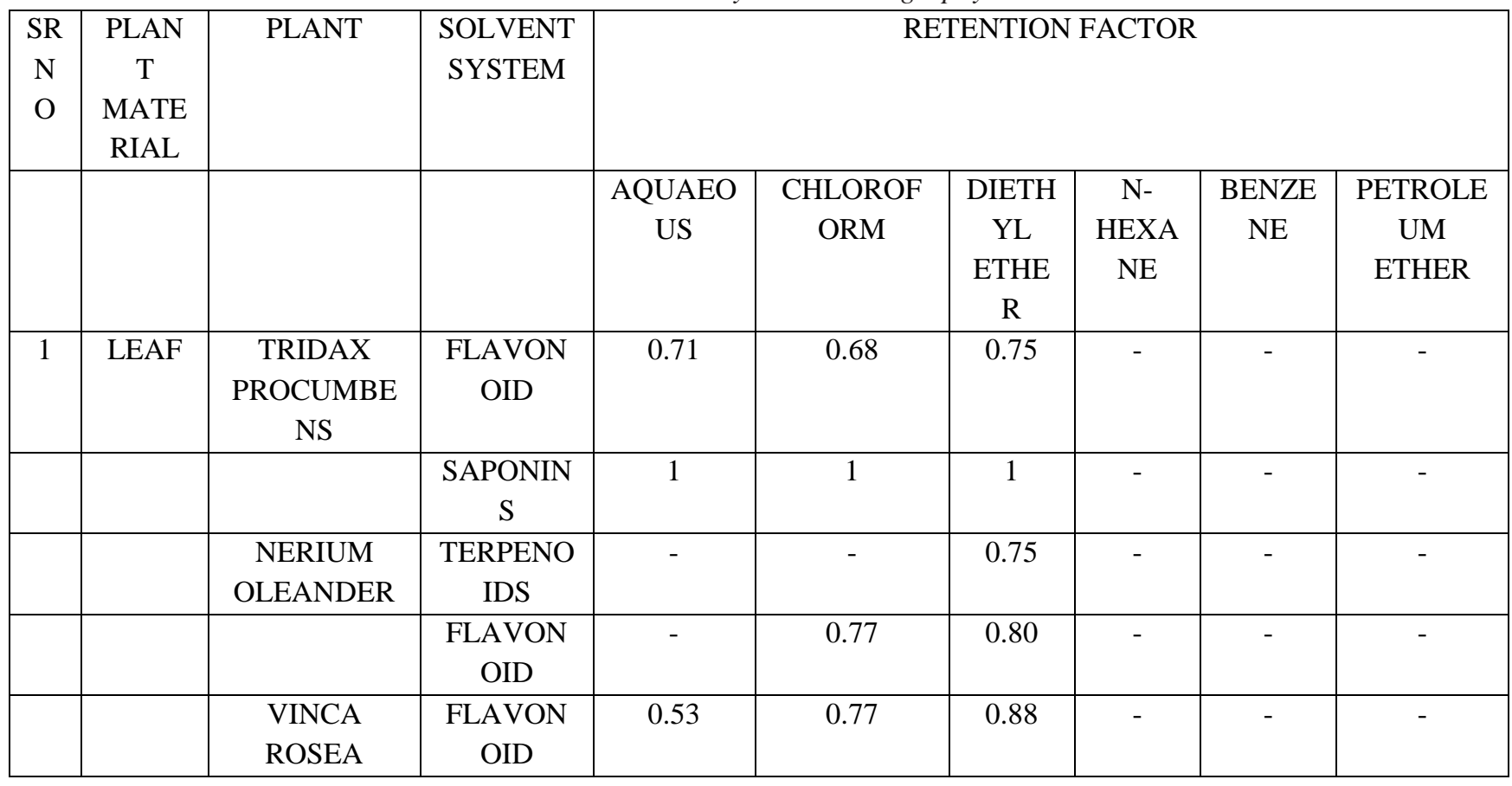


Table.4: Thin Layer chromatography

\begin{tabular}{|c|c|c|c|c|c|c|c|c|c|}
\hline \multirow{2}{*}{$\begin{array}{l}\mathrm{S} \\
\mathrm{R} \\
\mathrm{N} \\
\mathrm{O}\end{array}$} & \multirow{2}{*}{$\begin{array}{c}\text { PLANT } \\
\text { MATER } \\
\text { IAL }\end{array}$} & \multirow[t]{2}{*}{ PLANT } & \multirow[t]{2}{*}{ SOLVENT SYSTEM } & \multicolumn{6}{|c|}{ RETENTION FACTOR } \\
\hline & & & & $\begin{array}{c}\text { AQUAE } \\
\text { OUS }\end{array}$ & $\begin{array}{c}\text { CHLOROF } \\
\text { ORM }\end{array}$ & $\begin{array}{c}\text { DIETH } \\
\text { YL } \\
\text { ETHE } \\
\text { R }\end{array}$ & $\begin{array}{c}\mathrm{N}- \\
\text { HEXA } \\
\mathrm{NE}\end{array}$ & $\begin{array}{c}\text { BENZE } \\
\text { NE }\end{array}$ & $\begin{array}{c}\text { PETROLE } \\
\text { UM } \\
\text { ETHER }\end{array}$ \\
\hline 2 & STEAM & $\begin{array}{c}\text { TRIDAX } \\
\text { PROCUMB } \\
\text { ENS }\end{array}$ & FLAVONOID & - & - & - & - & - & - \\
\hline & & & SAPONINS & - & - & - & 1.8 & 1.6 & - \\
\hline & & & $\begin{array}{l}\text { CHLOROFORM: } \\
\text { METHANOL }\end{array}$ & - & - & - & 1.5 & - & - \\
\hline & & & $\begin{array}{l}\text { CHLOROFORM: } \\
\text { ACETONE }\end{array}$ & - & - & - & 1.12 & 1.1 & - \\
\hline & & $\begin{array}{c}\text { NERIUM } \\
\text { OLEANDE } \\
\mathrm{R} \\
\end{array}$ & FLAVONOID & - & - & - & - & - & - \\
\hline & & & SAPONINS & - & - & - & 2.16 & 1.48 & 1.75 \\
\hline & & & $\begin{array}{l}\text { CHLOROFORM: } \\
\text { METHANOL }\end{array}$ & - & - & - & - & - & 2.20 \\
\hline & & & $\begin{array}{l}\text { CHLOROFORM: } \\
\text { ACETONE }\end{array}$ & - & - & - & - & - & - \\
\hline & & $\begin{array}{l}\text { VINCA } \\
\text { ROSEA } \\
\end{array}$ & FLAVONOID & - & - & - & - & - & - \\
\hline & & & SAPONINS & - & - & - & 2 & 1.80 & 1.50 \\
\hline & & & $\begin{array}{c}\text { CHLOROFORM:MET } \\
\text { HANOL }\end{array}$ & - & - & - & - & - & - \\
\hline & & & $\begin{array}{l}\text { CHLOROFORM: } \\
\text { ACETONE }\end{array}$ & - & - & - & - & - & - \\
\hline
\end{tabular}

6.3 Results for Rate of Infection

Table.5: Study of infection rate in cotton

\begin{tabular}{|c|c|c|}
\hline MONTH & STAGE & NUMBER \\
\hline JUNE & NYMPH & $5-6$ \\
\hline & CRAWLERS & $2-3$ \\
\hline & ADULT & 0 \\
\hline JULY & NYMPH & 0 \\
\hline & CRAWLERS & $20-30$ \\
\hline & ADULT & 10 \\
\hline August & NYMPH & 0 \\
\hline & CRAWLERS & $60-90$ \\
\hline & ADULT & 30 \\
\hline
\end{tabular}


6.4 Results for Bioactive Activity

Table.6: bioactive activity of Plant extracts on cotton whitefly

\begin{tabular}{|c|c|c|c|c|}
\hline PLANT & $\begin{array}{c}\text { PLANT } \\
\text { MATERIAL }\end{array}$ & $\begin{array}{c}\text { NO. OF } \\
\text { CRAWLERS } \\
\text { BEFORE } \\
\text { TREATMENT }\end{array}$ & $\begin{array}{c}\text { NO. OF } \\
\text { CRAWLERS } \\
\text { AFTER } \\
\text { TREATMENT }\end{array}$ & $\begin{array}{c}\text { PERCENT OF } \\
\text { MORTALITY }\end{array}$ \\
\hline $\begin{array}{c}\text { TRIDAX } \\
\text { PROCUMBENS }\end{array}$ & LEAF & 61 & 36 & $40.9 \%$ \\
\hline $\begin{array}{c}\text { NERIUM } \\
\text { OLEANDER }\end{array}$ & STEM & 66 & 39 & $40.9 \%$ \\
\hline & LEAF & 55 & 36 & $34.45 \%$ \\
\hline VINCA ROSEA & LEAF & 56 & 33 & $41.07 \%$ \\
\hline & STEM & 36 & 37 & $39.34 \%$ \\
\hline
\end{tabular}

6.5 Result for Antifungal activity by well diffusion method

Table.7: Antifungal activities by well diffusion method

\begin{tabular}{|c|c|}
\hline PLANT & ZONE OF INHIBITION \\
\hline TRIDAX PROCUMBENS & $1.3 \mathrm{~mm}$ \\
\hline NERIUM OLEANDER & $1.2 \mathrm{~mm}$ \\
\hline VINCA ROSEA & $1.2 \mathrm{~mm}$ \\
\hline GENTAMYCIN & $0.5 \mathrm{~mm}$ \\
\hline
\end{tabular}

6.6 Result of Treatment of Infected plants

Table.8: Treatment of Infected Plants

\begin{tabular}{|c|c|c|}
\hline & TREATED SPLING & UNTREATED SAPLING \\
\hline SAPLING GROWTH & 7 days & 7 days \\
\hline $\begin{array}{c}\text { SAPLING INFECTED BY } \\
\text { FUNGUS }\end{array}$ & 15 -20days & 10 days \\
\hline
\end{tabular}

\section{FIGURES}

7.1 Selection of plants and preparation of extracts:
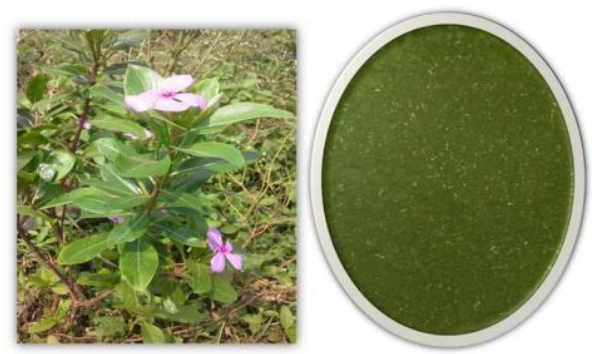

Fig.1: V. rosea and its powder 


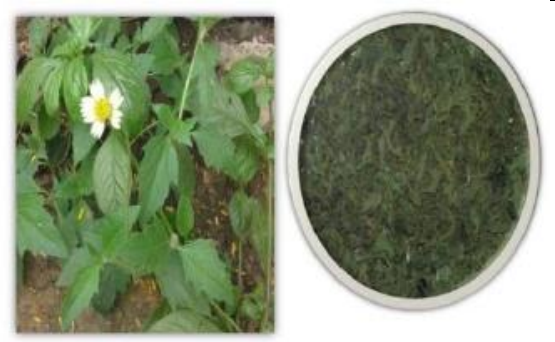

Fig.2: T. procumbens and its powder.
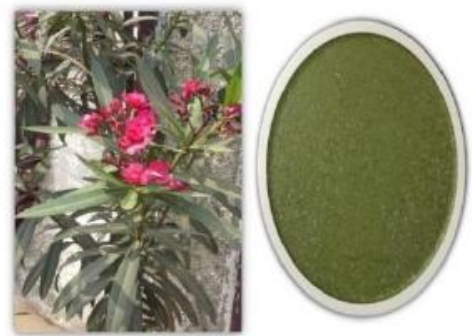

Fig.3: N. oleander and its powder

7.2 Thin Layer Chromatography:
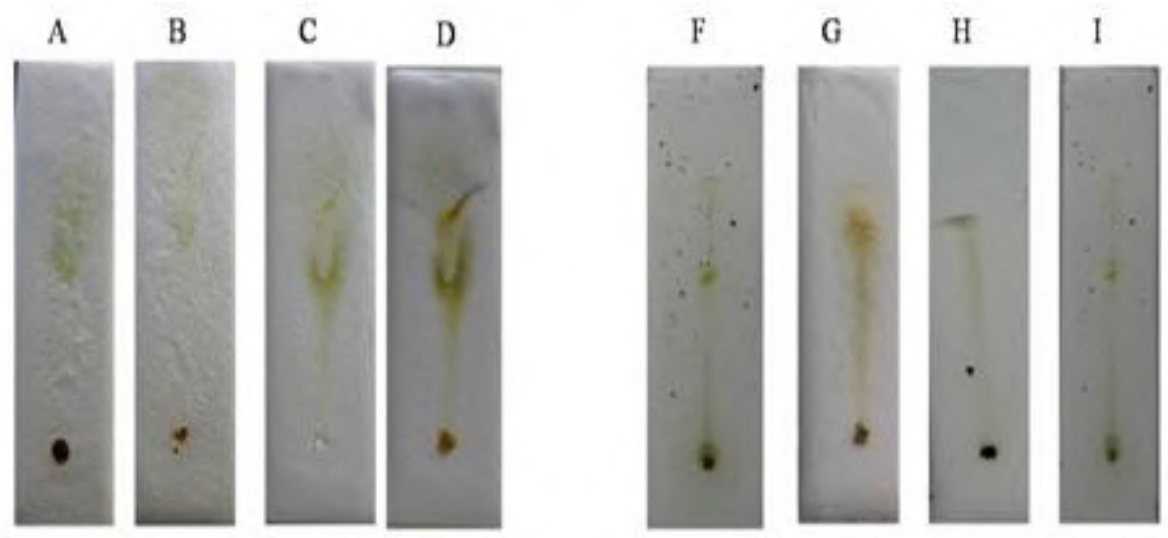

Fig.4: TLC Plates

7.3 Isolation and Cultivation of Fungus

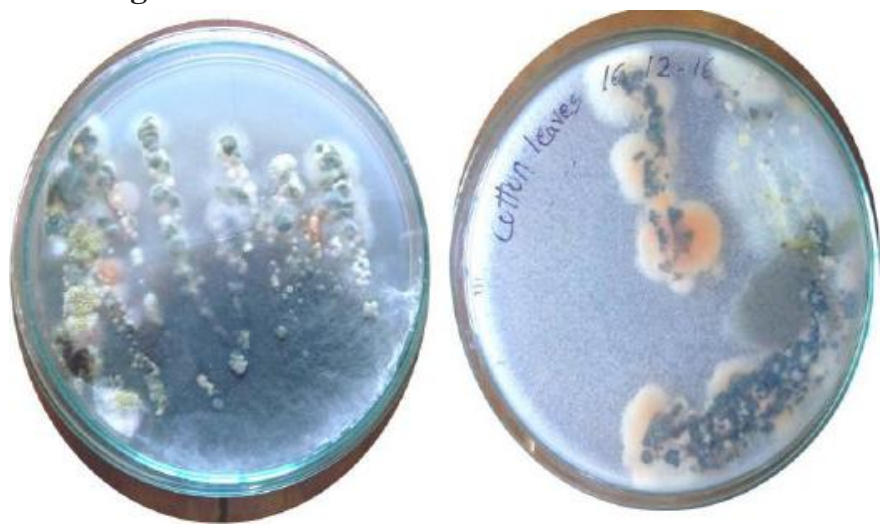

Fig.5: Plates showing fungal culture 
7.4 Microscopic analysis of fungal culture
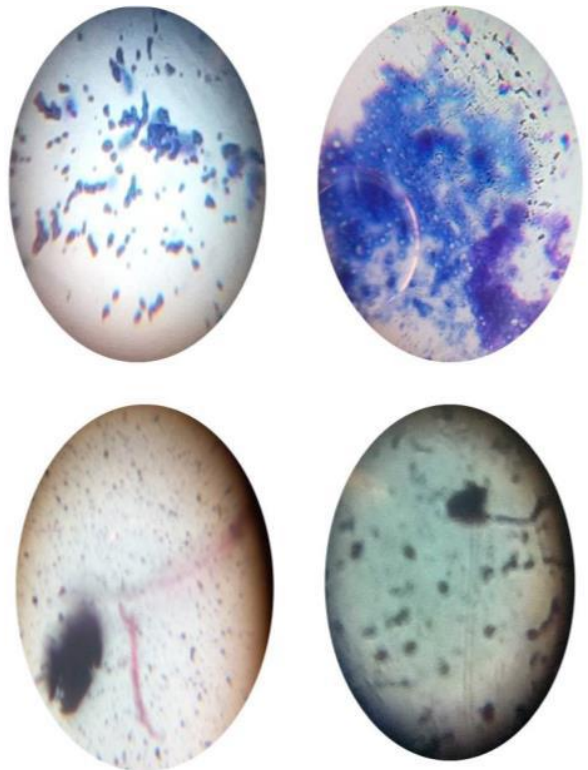

Fig.6: Microscopic identification of the fungal culture by gram staining

7.5 Antifungal Activity
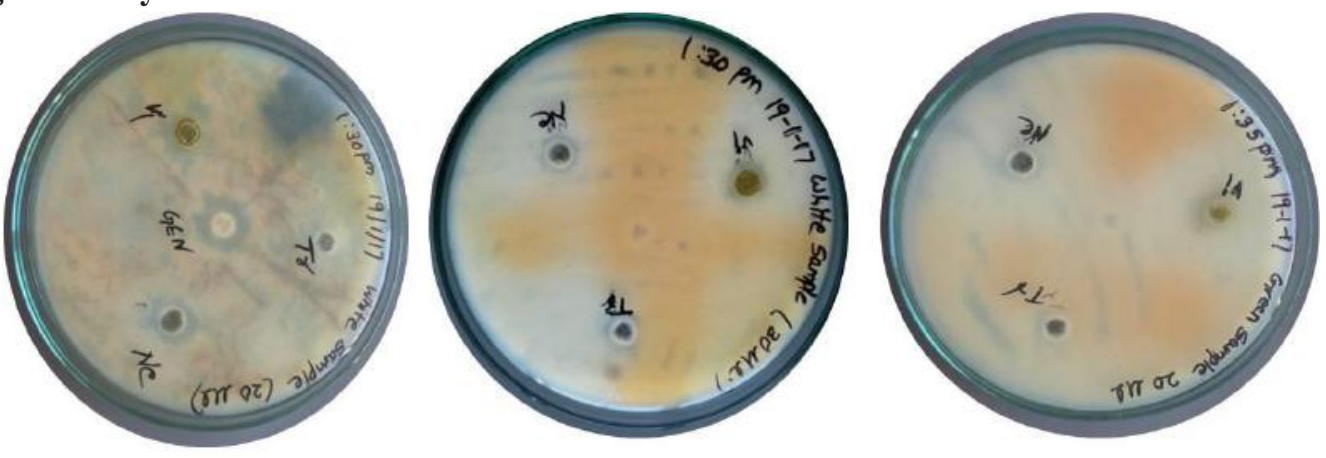

Fig.7: Plates showing antifungal activity of extracts on Mucor species.
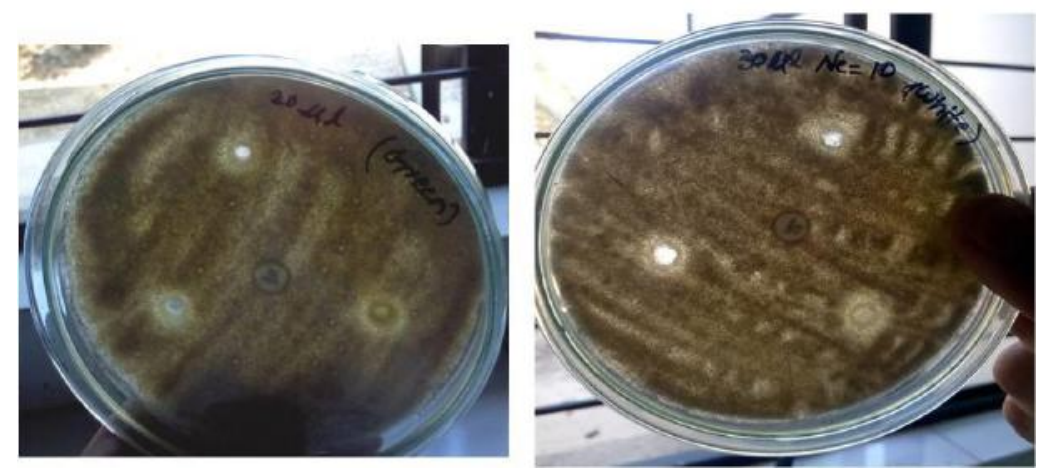

Fig.8: Plates showing antifungal activity of extracts on Aspergillus niger. 
7.6 Lab trial of Plants

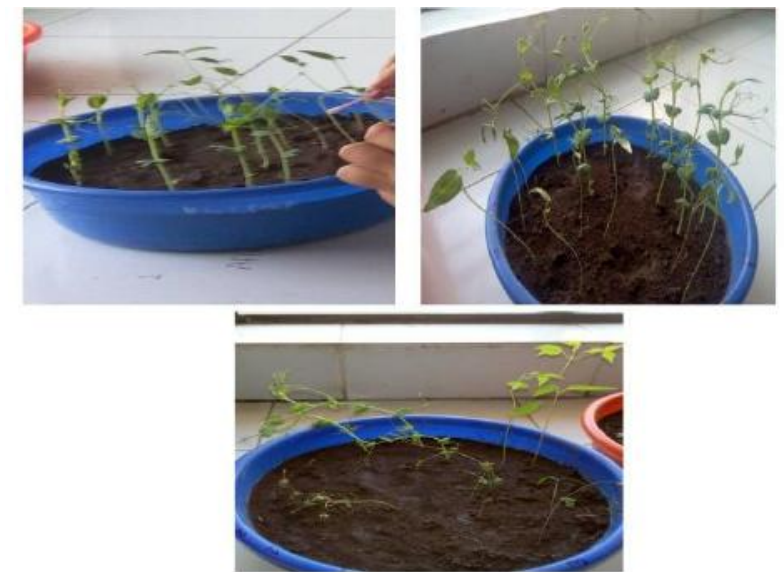

Fig.9: showing before and after infection to $V$. radiata and $V$. aconitafolia
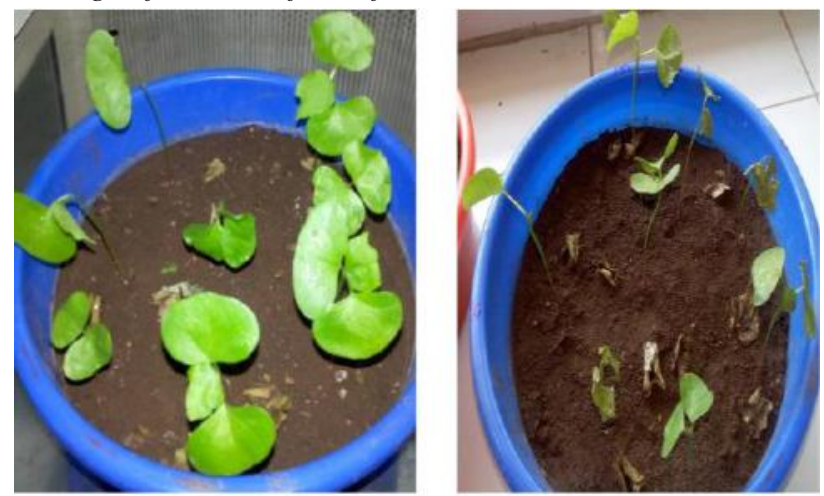

Fig.10: Showing before and after treatment to cotton plants.

\section{ACKNOWLEDGEMENT}

The authors are very grateful to Dr. Oli A.M. (Coordinator and Head of Department of Biotechnology, V.G.Shivdare College of Arts, Commerce and Science) and Dr. Aadki V.S. (Assistant professor, V.G.Shivdare College of Arts, Commerce and Science) for their valuable support, knowledge and encouragement to complete our research work fruitfully.

\section{REFERENCES}

[1] "Handbook of cotton plant health", Central Institute for cotton research.

[2] A.Manjumalai, R. Sardar Sathyajit Singh, C. Guruvayooorappan And V. M. Berlin Grace 2010 Analysis Of Phytochemical Constituents And AntiMicrobial Activityof Some Medicinal Plants In Tamilnadu, India Global Journal Of Biotechnology And Biochemistry 5 (2): 120-128.

[3] Abou - Fakhr Hammad et al, 2014. Bioactivity of endogenous medicinal plants against cotton whitefly, Bemisia tabaci. Journal of Insect science. Vol 14.1-18.
[4] Ali Ben Belgacem, Mohamed Sadok Bel-Kadhi, Refki Ettaieb 2016. Effects Of Temperature And Host-Plant Variability On Bemisia Tabaci (Homoptera, Aleyrodidae) Biology Journal Of Entomology And Zoology Studies. 4(2): 86-90.

[5] Alka Jindal, Padma Kumar 2013 Extraction and Quantification of Sterols from Tribulus Terrestris L., Sida Acuta Burm F. And Tridax Procumbens L. International Journal of Current Pharmaceutical Research Vol 5 95-97.

[6] Ankita Jain and Amita Jain 2012 Tridax Procumbens (L.): A Weed With Immense Medicinal Importance: A Review International Journal of Pharma and Bio Sciences Vol 3. 544-552

[7] Boykin LM, Shatters RG, Rosell RC, McKenzie CL, Bagnall RA, De Barro P. Global relationships of Bemisia tabaci (Hemiptera: Aleyrodidae) revealed using Bayesian analysis of mitochondrial COI DNA sequences. Mol. Phylogen. Evol. 2007; 44:1306-1319.

[8] Jafarbeigi, F., et al. "The effect of some herbal compounds on biological parameters of Bemisia tabaci (Genn.) (Hem: Aleyrodidae) on tomato under 
controlled conditions." J. Plant Prot. Res 52.4 (2012): 375-380.

[9] Jaydeep Halder, Chitra Srivastava And Prem Dureja 2015 Effect Of Methanolic Extracts Of Periwinkle (Vinca Rosea) And Bottlebrush (Callistemon Lanceolatus) Alone And Their Mixtures Against Neonate Larvae Of Gram Pod Borer (Helicoverpa Armigera) Indian Journal Of Agricultural Sciences 80 (9): 820-823

[10] K.R.Kranthi 2015 Whitefly the Black story, Cotton statistics and news.

[11] Khan Ia, Wan F-H 2015 Life History Of Bemisia Tabaci (Gennadius)(Homoptera: Aleyrodidae) Biotype B On Tomato And Cotton Host Plants Journal Of Entomology And Zoology Studies 2015; 3 (3): 117-121

[12] Lopez-Avila A. Two new of Encarsia (Hymenoptera: Aphelinidae) from Pakistan, associated with the cotton whitefly, Bemisia tabaci (Gennadius) (Hemiptera: Aleyrodidae). Bull Entomol Res. 1987; 77(3):425-430.

[13] Mahdavi Arab, N., et al. "Insecticidal effects of some plant extracts on Callosobruchus maculatus F. under laboratory condition and Laphigma exigua $H$. in greenhouse." JWSS-Isfahan University of Technology 11.42 (2008): 234-221.

[14] McKensie CL, Anderson PK, Villareal N. An extensive survey of Bemisia tabaci (Homoptera: Aleyrodidae) in Agricultural ecosystems in Florida. Florida Entomol. 2004; 87(5):403-407.

[15] R. Raveen, K.T. Kamakshi, M. Deepa, S. Arivoli And Samuel Tennyson.2014 Larvicidal Activity Of Nerium Oleander L. (Apocynaceae) Flower Extracts Against Culex Quinquefasciatus Say (Diptera: Culicidae). International Journal Of Mosquito Research 2014; 1 (1): 38-42

[16] Saeideh Esmaeily, Mohammad Amin Samih1, Mehdi Zarabi2, Fatemeh Jafarbeigi1 2014 Sublethal effects of some synthetic and botanical Insecticides On Bemisia Tabaci (Hemiptera: Aleyrodidae) Journal Of Plant Protection Research Vol. 54, No. 2 171-178.

[17] Santhi R. 2011 Phytochemical Screening Of Nerium Oleander Leaves And Momodica Charantia Leaves International Research Journal Pharmacy 2(1) 131-135

[18] Scott D. Stewart 1914. Agricultural extension service. University of Tennessee

[19] Sowmya B. Jhample, Sanjivani B. Gajdhane , Pramod J. Kasabe , Prashant K. Bhagwat And Padma B. Dandge 2015 Phytochemical Screening And In Vitro Antimicrobial Activity Of Tridax Procumbens L.
Research Journal Of Life Sciences, Bioinformatics, Pharmaceutical And Chemical Science .46

[20] The magazine of University of Arizona a cooprporative extension IPM Sr. no. 18, 5/2006.

[21] Oloyed, O.I. 2005. Chemical profile of unripe pulp of Caricapagaya. Pak. J. Nutr. 4: 379-381. 